\title{
SECTION 304, TAFT-HARTLEY ACT: VALIDITY OF RESTRICTIONS ON UNION POLITICAL ACTIVITY
}

Foldowing several attempts by both AFL and CIO unions to challenge the validity of Section 304 of the Taft-Hartley Act, ${ }^{1}$ the Department of Justice recently has instituted separate prosecutions against the $\mathrm{CIO}$ and its president, Philip Murray, for publishing and circulating newspapers commenting on Congressional and Presidential candidates; and against Local 481 of the AFL Painters' Union for advertising political opinion in the press and over the radio. ${ }^{2}$ Sustaining a motion to dismiss the indictment of the CIO and its president, the District Court for the District of Columbia has ruled that Section 304, insofar as it prohibits political "expenditures" by labor organizations, contravenes the First Amendment. ${ }^{3}$

The Section under which indictments were returned imposes criminal penalties on corporations as well as labor organizations making either "expenditures" or "contributions" in connection with federal elections." This discus-

1. 61 Stat. 159, 2 U.S.C.A. App. § 251 (Supp. 1947) (hereinafter cited as §304), amending, 43 StAT. 1070 (1925), 2 U.S.C. $\$ 251$ (1940) (Corrupt Practices Act of 1925).

2. Soon after passage of $\$ 304$, the CIO issued a "1947 Voting Guide" for members and endorsed a candidate in a Maryland special election in the CIO NEws and elsewhere. N.Y. Times, Aug. 11, 1947, p. 1, col. 5. See statement by Philip Murray, President of the CIO in CIO News, July 14, 1947, p. 1. For indications of increased CIO-PAC political activity accentuating voluntary contributions, see N.Y. Times, July 11, 1947, p. 3, col. 2. The Connecticut Federation of Labor also made early attempts to provoke the Justice Department into action with publicized violations. See N.Y. Times, Aug. 7, 1947, p. 11, col. 2.

The Department of Justice initiated action on February 11, 1948, eight months after the passage of the Act. See N.Y. Times, Feb. 12, 1948, p. 1, col. 5. Attorney General Clark invited Congress to join the Department of Justice in the prosecution, asking the Joint Committee on Labor-Management Relations to name a lawyer who would participate in the Government's case. N.Y. Herald Tribune, Feb. 26, 1948, p. 1, col. 4. The Department of Justice has occasionaliy in the past invited Congressional Counsel to assist in the enforcement of a controversial statute. In this instance, however, the Committee declined to participate. N.Y. Herald Tribune, Feb. 27, 1948, p. 1, col. 7. For indictment of the CIO, see N.Y. Times, supra; for the indictment of the AFL Painter's Union, see the Hartford Courant, Feb. 19, 1948, p. 1, col. 4.

3. United States v. Murray, N.Y. Times, March 16, 1948, p. 24, col. 1, cerl. granted N.Y. Times, March 30, 1948, p. 24, col. 2.

4. Section 304 reads in part, "It is unlawful . . . for any corporation whatever, or any labor organization to make a contribution or expenditure in connection with any election at which Presidential and Vice Presidential electors or a Senator or Representative in, or a Delegate or Resident Commissioner to Congress are to be voted for, or in connection with any primary election or political convention or caucus held to select candidates for any of the foregoing offices, or for any candidate, political committec, or other person to accept or receive any contribution prohibited by this section. Every corporation or labor organization which makes any contribution or expenditure in violation of this section shall be fined not more than $\$ 5,000$; and every offecr or director of any corporation, or officer of any labor organization, who consents to any contribution or expenditure by the corporation or labor organization ... . in violation of this section shall 
sion, however, is confined to a constitutional evaluation of Section 304 as it applies to labor organizations ${ }^{5}$ since it is this aspect which currently occupies the attention of the courts.

\section{SCOPE of Section 304}

Passed with little debate, ${ }^{\circ}$ Section 304 ostensibly carries forward a program of "corrupt practices" legislation" instituted half a century ago. Since 1906, Congress has, with minimal success, attempted to exercise some control over corporate and individual political contributions and over political expenditures by national committees and candidates. ${ }^{8}$ Not until 1943 , however, was Con-

be fined not more than $\$ 1,000$ or imprisoned for not more than one year, or both."

Neither $\$ 304$ nor cognate legislation restricts political expenditures unrelated to elections. Such expenditures are regulated to some extent by the Federal Lobbying Act, 41 STAт. 68, 18 U.S.C. \$201 (1940) ; See Comment, Introving the Legislative Proeess: Federal Regulation of Lobbying, 56 YAIE L. J. 304 (1947).

5. This delimitation necessarily raises the issue of separability. But if, on the one hand, the Act were held constitutional as it applies to labor unions, it seems unlikely that any court would declare it unconstitutional as it applies to corporations. Cf. Anniston Mffg. Co. v. Davis, 301 U.S. 337, 351-2 (1936). If, on the other hand, the Act were held unconstitutional vis-à-vis labor, it would seem to be tampering with congressional intent to suppose that it might be allowed to remain on the books as an integrated cnactment directed solely at corporations.

6. Neither the House Labor Committee nor the Senate Labor and Education Committee, which heard testimony on bills which subsequently became the Labor-Management Relations Act of 1947, heard testimony on $\$ 304$. It was scarcely debated in the House, where it originated, and was debated but part of one day, June 5, 1947, in the Senate. See 93 CoNG. REC 6436-6441 (1947).

7. The history of "corrupt practices" legislation is a well told tale. Consult generally, Logan, The Adrerican Political Scene 170 (1936); Oreracker, Presmbaitual Caripaign Funds (1946); Pollock, Mfoney and Polttics Abrond (1932); Pollock,

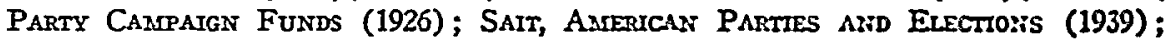
Sikes, State and Federal Corrupt-Practices Legislation (1928).

Textbooks on American political science often contain useful summaries of material on "corrupt practices" legislation. See, e.g., KEY, Polmtrcs, Parties Arid Pressume Groups (1942), esp. c. 15; Merriasr and Gosmely, The Ayrenican Pafti Systexs (1946), esp. c. 16; Odegard and Heluss, Amrerican Poltics (1938), esp. c. 19. See also Pollock, Campaign Fatnds in 1928, 23 Ass. PoL. Scr. Rev. 47 (1929).

8. The 1906 legislation prohibited corporations from making "money" contributions in connection with federal elections, 34 STAт. 854 (1907), 35 STAт. 1103 (1909), in order to free party policy from corporate influence. Prior to its enactment, banks, insurance companies, manufacturers and public utility companies were regular contributors, on a notably non-partisan basis, either to the stronger party, or to both parties. See Osmogorski, Democracy" and the Organization of Polttical Parties 180 (1922); Crol\%;

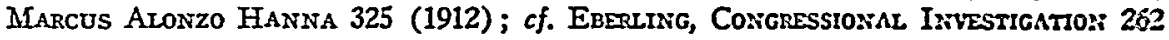
(1928). The validity of the ban on corporation contributions was sustained in the one successful prosecution brought thereunder, although the district court decision was not appealed. United States v. United States Brewers' Ass'n., 239 Fed. 163 (W.D. Pa. 1916). The statute did not, however, prevent corporate political assistance in the form of advertising expenditures. See OvERACKER, MfoNex IN ELECTIONs 335 (1932); Overacker, Campaign Funds in the Presidential Election of 1936, 31 Asr. Por. Scr. REv. 473, 
gressional action directed toward the regulation of labor union political activity. ${ }^{9}$ By Section 9 of the temporary Smith-Connally Act, ${ }^{10}$ labor organiza-

479-80 (1937); Clark, Federal Regulation of Election Campaign Activities, 6 FED. B. J. 5,8 (1944). In addition, corporate officers and those who held controlling interests in corporations made substantial individual contributions which spoke for corporate policies. See Odegard And Heldss, op. cit. supra note 7 at 658; Overacker, Money iN Elections 158, 159, 336 (1932) ; Overacker, Campaign Funds in a Depression Year, 27 AM. Por. Scr. Rev. 769 (1933); Overacker, Campaign Funds in 1936, 31 Arr. Poz. Scr. Rev. 473 (1937).

Legislative attention accordingly shifted to publicizing individual contributions, and in 1911 the first federal pre-election publicity law was passed, requiring reports of contributions to and expenditures by political committees, with limitations on expenditures by individual candidates. 37 STAT. 25 (1911), 2 U.S.C. $\$ 244$ (1940), amending 36 STAT. 823 (1910). But the limitations proved meaningless and little publicity resulted. The Corrupt Practices Act of 1925, 43 STAT. 1070 (1925), 2 U.S.C. $\$ \$ 241-256$ (1940), merely consolidated and modified previous legislation. See OvERACKER, PRESIDENTIAL Campatgn Funds 22 (1946).

In 1940, Congress instituted a new program of prohibition in the second Hatch Act, placing a $\$ 5000$ per year limit on individual contributions to national committees and candidates, and a $\$ 3,000,000$ per year limit on expenditures by the committees themselves. 54 STAT. 767, 772, 18 U.S.C. $\$ 61$ (1940). Since only national committees were affected, however, individual contributions were channeled easily into state and local political agencies. See SEN. Rep. No. 47, 77th Cong., 1st Sess. 143-191 (1941); Overacker, Campaign Finance in the Presidential Election of 1940, 35 Ars. PoL. Sar. Rev. 701 (1941). And even national committees could be financed in part by the aggregation of numerous $\$ 5000$ gifts from single families whose financial resources permitted substantial political contributions, or by loans which were not repaid. See SEN. REP. No. 47, supra at 143-8; KEY, op. cit. supra note 7, at 664-5. The creation of a number of non-party organizations in addition to the major national committees, -each of whose expenditures could total $\$ 3,000,000$, - made ineffective the limitation on expenditures. Such groups as "Associated Willkie Clubs of America," "Democrats for Willkie," "We the People," "National Committee of Physicians for Willkie," and "National Committee of Independent Voters for Roosevelt and Wallace" spent over $\$ 3,500,000$. Moreover, each of these groups was theoretically empowered to receive as much as $\$ 5000$ from each contributor. See H.R. Rep. No. 2093, 78th Cong., 2d Sess. 3-4, 9-10 (1945), and Overacker, Presidential Can!paign Funds, 1944, 39 Axr. Por. Scr. Rev. 899, 905 (1945). As a result the total amount spent in the 1940 election was $\$ 21,000,000$, and in the 1944 election, $\$ 20,500,000$, in contrast to a previous total expenditure, in the halcyon 1928 election, of $\$ 16,500,000$. SwN. REP. No. 47, supra at 10, 11, and tables, 106-42 (1941) (1940 data); SEN. REP. No. 101, 79th Cong., 1st Sess. 79 (1945) (1944 data). See Overacker, Presidential Campaign Funds, 1944, 39 Ax. Pol. Scr. Rev. 899, 916 (1945).

9. Several states have attempted to regulate contributions and expenditures by labor unions, in most cases unsuccessfully. See ALA. CoDE, tit. 26, $\$ 392$ (Supp. 1943), (forbidding political contributions by unions); Coro. Stst. ANv., c. 97, $\S 94$ (20) (Cum. Supp. 1946) (forbidding political expenditures by trade unions); Ore. CoMr. LAws ANN. \$102-909 (1940) (prohibiting the creation of "a fund in excess of the legitimate requirements of the union."); PA. STAT. ANN., tit. 25, \$3225 (Purdon, 1941) (forbidding contributions by unincorporated associations); TEx. Civ. StAT. ANN., tit. 83, art. 5154a, $\S 49$ (Vernon, 1947) (forbidding contributions to candidates or political parties).

The Alabama limitation on political contributions by labor organizations, part of a comprehensive labor regulation act, was struck down in Alabama State Federation of Labor v. McAdory, 246 Ala. 1, 18 So.2d 810 (1944). The Alabama Supreme Court 
tions were barred from making "contributions" in connection with federal elections. ${ }^{11}$ But the statute had little practical effect. In deference to $N$ ca'berry $v$. United States, ${ }^{12}$ Congress had excluded primary elections from the purview of the Act. Further, such groups as CIO-PAC ${ }^{13}$ were construed not to be "labor organizations."14 Finally, labor reorganized its method of political

held that a provision in the act prohibiting an organization of employers from maling political contributions was invalid under $\$ 45$ of the Alabama Constitution since it bore "no relation to the subject of the Act." Id. at 24, 18 So. $2 \mathrm{~d}$ at 830 . The court reasoned further that since the "intent" of the legislature had been to equalize employers and cmployees, where employers were freed of the prohibition, employees must likewise be unrestrained, in spite of the separability clause in the act. The Colorado prohibition fell in AFL v. Reilly, 113 Colo. 90, 155 P.2d 145 (1944) (inseparable from unconstitutional requirements of incorporation). The Oregon prohibition fell as inseparable from other unconstitutional aspects of the statute, although the prohibition itself was not specifically voided, since not tested, in AFL v. Bain, 165 Ore. 183, 105 P.2d 544 (1940). A proposed initiative law in Massachusetts which would have limited expenditures and contritutions by labor unions was struck down by the Mrassachusetts Supreme Court as violative of the freedom of press provision of Misss. Const., AxIEND. 48, The Initiative, II, §2. Bowe $v$. Secretary of the Commonwealth, 320 MFass. 230, 69 N.E.2d 115 (1946). The Tevas prohibition was upheld, however, in AFL v. Mann, 188 S.W.2d 276, 283 (Tex. Civ. Agp. 1945) on the basis that Congress had passed similar legislation in the Smith-Connally Act. Since the law dealt only with contributions, the court felt that the right of the union to educate or inform its members as to the merits or demerits of candidates or political parties was not abridged.

For discussion of state legislation see Note, State Regulations of Labor Unions, 55 YaIe L. J. 440 (1946) ; Dodd, The Supreme Court and Organized Labor 1941-1045, 58 HARv. L. Rev. 1018, 1061 (1945); Dodd, Some State Legislatures Go to Wor-On Labor Unions, 29 Iowa L. Rev. 148 (1944); Villard, WYhy Unions Mfust be Regulated, 58 AxIER. Miercury 667 (1944); Milner and Brissenden, Union Regulation by the Stales, 103 NEw Republic 790 (1943); Taper, Dizie Driz'c on Labor, 154 NAtions 569 (1942); Smith and DeLancey, The State Legislatures and Unionism, 38 14rce. L. Rev. 987 (1940).

10. War Labor Disputes Act of 1943, 57 SrAT. 163 (1943), 50 U.S.C. APp. $\$ 1501$ (Supp. 1944). The Act expired by its terms June 30, 1947. See Note, The Srribi-Consally Act, 3 LAw. Gumd Rev. 46, 50-1 (July-Aug. 1943).

11. The prohibition on contributions was not germane to the main purpose of the Act,

- which purportedly was an emergency measure aimed to prevent strikes in wartime, and there was little discussion of that issue. The Senate apparently accepted the prohibition in order to expedite passage of the entire bill, with an understanding that $\$ 9$ would be amended later. $\$ 9$ CoNG. REC. 5721, 6488 (1943).

12. 256 U. S. 232 (1921).

13. CIO-PAC was organized in response to prohibitions on contributions by labor organizations in the Smith-Connally Act. It was felt that a new organization was neaded to integrate all political activity. Through CIO-PAC, the CIO is believed to have exerted a major influence on the 1944 Presidential elections. Petrrsors, Arrerscar Lacon Usions 36 (1945).

Literature on its activities is voluminous. The most complete description is contained in GaEr, The FIRst Round (1944). See also, c.g., Fuller, Labor and Politics, 110 NiEw REPUBLIC 111 (1944); Hillman, Truth About the P.AC, 111 NEW REpunus 209 (1944); Waldman, Will the CIO Capture the Democratic Party?, Sat. Eve. Post, Aug. 26, 1944, p. 22.

14. See Letter from the Atty. Gen. to Sen. Micore dated Sept. 23, 1944, Dep't. of Justice Press Release, Sept. 25, 1944. See also Defartment of Justice Clcars PAC, 4 Law. GUIID REv. 49 (Sept-Oct. 1944). 
financing so as to provide for direct political action rather than union contributions to candidates and parties. ${ }^{15}$

Section 304 reaches two areas of political activity hitherto free from Congressional regulation. First, encouraged by the Supreme Court's decision in United States $v$. Classic, ${ }^{10}$ Congress has extended its control of the electoral process to include primaries, conventions, and caucuses. Second, Congress has supplemented its ban on "contributions" by adding the crucial term "expenditures." 17 It is this particular extension of "corrupt practices" legislation which gives rise to current controversy. ${ }^{18}$

Since practically all of a labor organization's political activity is financed directly from its general treasury rather than from the resources of individual union members, a literal construction of the term "expenditures" would virtually prohibit all political action by unions "in connection with federal elections." 19 It is possible to interpret the proscription on expenditures to include

15. Funds were collected by CIO-PAC from individual unions before the nominating conventions. Part of these were spent before July 23, 1944. On that date the remaining funds were "frozen," and none of them went into the final election campaign. Instead, CIO-PAC appealed for voluntary contributions-"A Buck for Roosevelt." In addition, individual unions engaged in such direct political activity as pamphleteering, the purchase of radio time, publication of voting records of Congressmen, etc. For a full account of PAC finances see Overacker, Presidential CaMpaign Funds 55-71 (1946).

16. 313 U.S. 299 (1941). The decision narrowed the effect of the Newberry case by extending federal control of elections to primaries where the latter are an integral part of the entire election.

17. The Senate Special Committee to Investigate Presidential, Vice Presidential and Senatorial Campaign Expenditures as early as 1944 considered a recommendation to amend $\S 313$ of the Corrupt Practices Act to prohibit expenditures as well as contributions, but specifically rejected it, saying, "the extension of the prohibition to include expenditures would tend to limit the rights of freedom of speech, freedom of the press, and freedom of assembly as guaranteed by the Federal Constitution." See SEN. REP. No. 101, 79th Cong., 1st Sess. 83 (1945). By 1947 the Committee had changed its mind; it was recommended that "expenditures" be included within the restriction on contributions. See SEN. REP. No. 1, Part 2, 80th Cong., 1st Sess. 38, 39 (1947) and H. REp. No. 2739, 79th Cong., 2nd Sess. 39,40 (1946).

18. See statement by the late Joseph A. Padway, formerly AFL General Counscl, that AFL unions "would observe the ban on direct political contributions," but would violate the ban on expenditures. N.Y. Times, June 29,1947 , p. 1, col. 6 . The CIO also attacked only the proscription on expenditures, N. Y. Times, Aug. 17, 1947, p. 17, col. 1, and, consequently, the court in United States v. Murray, N.Y. Times, March 16, 1948, p. 24 , col. 1, did not pass on the constitutionality of the ban on contributions.

19. The "expenditures" provision also has serious implications for corporations. The President, in his veto message, pointed out that $\$ 304$ "can be interpreted as going far beyond its apparent objectives, and as interfering with necessary business activities. It provides no exemption for corporations whose business is the publication of newspapers or the operation of radio stations. It makes no distinctions between expenditures made by such corporations for the purpose of influencing the results of an election and other expenditures made by them in the normal course of this business in connection with an election'". N.Y. Times, June 21, 1947, p. 2, col. 7. Although Senator Taft attempted to avoid such an interpretation, 93 CoNG. REc. 6436 (June 5, 1947), the Department of Justice by implication indicated its agreement with the President. N.Y. Herald Tribunc, 
only those made from general union funds received by labor organizations in the form of dues, rather than from funds collected especially for political purposes in the form of voluntary contributions by union members. ${ }^{20}$ But the term "expenditure" is all-inclusive on its face, and as such seems to include any disbursement of money for a political purpose, whether direct or indirect. $^{21}$ Thus, a "contribution" may be considered as but one form of "ex-

July 11, 1947, p. 1, col. 3. In addition, the prohibition on "expenditures" may be interpreted as placing drastic limitations upon the activity of any political group, such as, for example, the League of Women Voters, which happens to be corporate in structure. See ibid., where the attorney for the League notified the organization officials that their actions were illegal. And what of the corporation which permits its employees to vote on company time without deducting from their pay? Cf. People v. Ford Motor Co., 271 App. Div. 141, 63 N.Y.S.2d 697 (3d Dep't 1946) ; Note, Pay While Voling, 47 CoL L. REv. 135 (1947).

20. A narrow construction of $\$ 304$ opens up a Pandora's Box of troublesome ambiguities. The indictment in United States v. Murray, stpra note 18, charged that the CIO Newos, a union newspaper financed by subscribers, had supported a congressional candidate. Yet prior to the Murray case Senator Taft had indicated that publication of a union newspaper would be proscribed if it were supported "by union funds contributed by union members as dues" but not if it derived its funds from subscribers. 93 Co:sc. Rec. 6436 (1947). Senator Ball had indicated further that expenditures derived from an "earmarked portion of the dues which the union collects and remits to the newspaper in the form of subscriptions" might be permissible. Id. at 6438. "Earmarking" then, is apparently necessary in order to attribute newspaper funds directly to the individual union member rather than to a forbidden source-the union. But what must be done to assure that the funds are "earmarked"? Senator Taft offered one solution when he suggested that "If they [union members] are asked to contribute directly to the support of a newspaper or to the support of a labor political organization, they know what their money is used for and presumably approve it." Id. at 6440 . His further remarks leave unclear whether the union would be allowed to employ mild coercion such as social stigma, and whether his interpretation requires "contracting in" or "contracting out"; but he has recently indicated that the aim of $\$ 304$ is "to prevent labor organizations from using their members' money" for political campaigns without the membership's complete consent." N.Y. Herald Tribune Feb. 26, 1948, p. 2, col. 3.

21. Representative Hartley announced that if $\S 304$ failed to express his view that no union newspaper, regardless of its method of financing, should be permitted to talie a stand on a political candidate, he would be "willing to amend the act to make it clear." N.Y. Herald, July 16, 1947, p. 3, col. 2.

Compare the interpretation offered by a New York Herald Tribune reporter, after an interview with Department of Justice officials concerning limitations on commercial newspapers, that the word "expenditure" "is not the ambiguous term it was thought to be during debate over the bill. . . . Another, and still effective, section of the original corrupt practices act defines an 'expenditure' broadly as 'anything of value' ... the expenditure of paper, ink, writing services and composing costs of any newspaper owned by 'any corporation' or labor union in publishing a political editorial is apparently a technical violation." N.Y. Herald Tribune, July 11, 1947, p. 1, col. 3.

It is difficult to find here one clear interpretation. It is suggested that if a narrow view was intended, it would have been simple to draft legislation specifically creating separate union political funds and assessments with the power of individual members to withhold "political dues." 
penditure."22 Within the scope of "expenditure" would be inclucled disbursements for publication of union newspapers, magazines, leaflets, and pamphlets. ${ }^{23}$

An even broader range of activities may be affected. Since payment from union funds of the salary of an organizer who makes political speeches is literally an expenditure, such activity may be forbidden. Where an umbilical cord has linked CIO and PAC, any activity by CIO fostering PAC could be interpreted as an expenditure, and thus prohibited. If "expenditure" is strictly interpreted, a union hall could not be placed at the disposal of a candidate or party; anyone who in the union name sought to propagandize for a candidate or party would do so at the union's peril; handbills and placards would be barred; paid newspaper and magazine advertisements and radio advertising would be similarly proscribed. A literal interpretation of "expenditure" thus bans any conceivable political action by the union in connection with federal elections. $^{24}$

Since it is the labor union which is concerned, one of a group of problems may be the definition of "labor organization." The definition in Section 304 is substantially similar to that of Section 9 of the Smith-Connally Act ${ }^{25}$ and of

22. Sections 302 (d) and 302 (e) of the original Corrupt Practices Act of 1925, 43 Stat. 1070 (1925), 2 U.S.C. $\$ 241$ (1940) define "contribution" and "expenditure" in such a way as to make differentiation almost impossible. Both expenditures and contributions are referred to as gifts, loans, advances, deposits of money or value, and contracts, promises, or agreements to make them. The only word exclusively characterizing a "contribution" is "subscription"; the exclusive words for "expenditure" are "payment" and "distribution". See generally 93 CoNG. REc. 6436 (1947).

23. Senator Taft, in explaining the bill, consistently distinguished as to the source of the publication's funds. If the newspaper or pamphlet was supported by union or corporation funds, its political activity would be proseribed by the Act; if supported by subscriptions, political activity would be allowable. See his statements in 93 CoNc. REc. 6436-7 (1947), and N. Y. Herald Tribune, July 11, 1947, p. 1, col. 3. But compare a possible additional distinction drawn by Senator Taft between a newspaper which is "a going concern" and one which is not. 93 CoNG. REC. 6438 (1947).

24. On July 10, 1947, Senators Aiken of Vermont and Hatch of New Mexico introduced into the Senate a bill (S. 1613) to amend the Act to permit political expenditures by unions. Senator Aiken pointed out that, as far as $\S 304$ was concerned, "it was realized by some that the bill went too far in restricting freedom of speech and of the press." N.Y. Times, July 12, 1947, p. 2, col. 3. Remarking on the lack of debate in Congress on $\$ 304$, Senator Hatch stated that if the section did infringe constitutional guarantees, "the question should be thoroughly explored here on the floor of the Senate." 20 LAD. REL. REp. 187 (1947). Representative McDonough of California introduced a bill (H.R. 4193) which would permit union papers to express preferences as to political candidates; provided a majority of the union so voted and with a certificate to this effect filed with the NLRB. Senator Taft pronounced himself opposed to the Aiken-Hatch Amendment but suggested that the new House-Senate Labor Committee study the advisability of changing the "expenditure" restrictions in $\$ 304$. Ibid. He later indicated, however, that he was "rigorously opposed" to changing the political expenditures provision before 1949. N.Y. Herald Tribune, Feb. 26, 1948, p. 2, col. 3.

25. The definition in $\$ 304$ reads, "For the purposes of this section Iabor organization' means any organization of any kind, or any agency or employee representation com- 
the original National Labor Relations Act of 1935.20 When demands were made in 1943 that the Department of Justice prosecute PAC as a labor organization, it was decided, inter alia, that, despite the CIO's close relationship with $\mathrm{PAC}$, the latter did not bargain with employers concerning working conditions and so would not be considered a labor organization within the meaning of Section 9.27 As a result, PAC itself apparently is free to engage in political activities. ${ }^{28}$

Another question likely to arise is the meaning of the phrase "in connection with" federal elections. While it seems to have no authoritative interpretation, one possible limitation, already observed with respect to the Smith-Connally Act, would confine its application to the period following the filing date for a federal candidate or for delegates to a nominating convention or caucus. $\approx$ Thus, a general educational campaign discussing political issues, if engaged in prior to the filing date, would not be forbidden. But an impartial presentation, after filing date, of the voting records of all candidates would be barred. On the other hand, the scope of "in connection with" might be extended to any campaign activity which bore on the status of a candidate or party, especially where candidacy is known in advance of filing, or where the political position of a party is generally cognizable.

\section{CONStitutional Issues}

Congressional regulation of federal elections has been sanctioned on the basis of those provisions of the Constitution which vest in Congress power to regulate Presidential and Congressional elections, ${ }^{30}$ and which have been

mittee or plan, in which employees participate and which exists for the purpose, in whole or in part, of dealing with employers concerning grievances, labor disputes, wages, rates of p3y, hours of employment, or conditions of work."

26. 49 STAT. 449 (1935), 29 U.S.C. $\$ 151$ (1940).

27. See note 14 supra.

28. Whether such organizations as the AFL Connecticut Federation of Labor would be included within the $\$ 304$ definition may be one of the litigated questions, although it seems fairly clear that both AFL and CIO as national organizations come within the meaning since they engage in dealing with employers, whereas State Federstions of Labor do not.

29. See Pressman, CIO Miemorandum No. 2, Re: Political Aclizity usnder ToftHartley Act (1947).

30. There is little question but that Article I, $\$ 4$ grants brosd power to Congress to regulate the manner of holding Congressional elections. United States v. Gradwell, 243 U.S. 476 (1917); cf. Smiley v. Holm, 285 U.S. 355 (1932). When Congress attempted to extend its control to Presidential elections, it encountered a barrier in that Article II, $\S 1, C l .2$ specifically vests in the states the power to regulate the manner of appointing Presidential electors. Cf. Is re Green, 134 U.S. 377 (1890) ; MrePherson v. Blacker, 146 U.S. 1 (1892). But in Burroughs and Cannon v. United States, 290 U.S. 534 (1934), where a requirement of publicity in the Corrupt Practices Act of 1925 concerning elections was contested, the Court sanctioned Congressional regulation of Presidential election. For a broad picture of Congressional power, consult Alaurer, Congressional and State Control of Elections Under the Constiintion, 16 GEo. L. J. 314, 324-27 
broadly interpreted for the protection of electoral processes from such "corrupt practices" as fraud and vote buying. Where, however, "corrupt practices" legislation seems seriously to curtail the expression of political opinion, a grave constitutional issue is presented. ${ }^{31}$ Inasmuch as Section 304 seems to provide a blanket prohibition on union political expression, a Supreme Court which is less insistent on "judicial self-restraint" where political processes are concerned $^{32}$ undoubtedly will scrutinize the section with great care. The presumption of validity which normally attaches to legislation tends to disappear where a statute impinges on freedom of speech, assembly and press as protected by the First Amendment. ${ }^{33}$

(1928). Another possible instrument for controlling election expenses lies in the commerce power. See cognate provision of Public Utility Holding Company Act of 1935, which forbade contributions to federal, state or local political campaigns by any registered utility holding company or subsidiary, 49 STAT. 823 (1935), 15 U.S.C. 79(1) (1940).

31. How the Court will interpret the word "expenditure" may be a kcy to the constitutionality of $\$ 304$. The Court may construe the term so loosely as to foreclose the need for a decision on constitutional grounds. For example, the Court might read into the meaning of "expenditure" a complex ritual of "contracting in" or "contracting out." See note 20 supra and pp. 820-1 infra.

It is also possible that $\$ 304$ is so vague, and Congressional intent so uncertain as to void this criminal statute under the due process clause of the Fifth Amendment. See, e.g., Lanzetta v. New Jersey, 306 U.S. 451 (1939); Stromberg v. California, 283 U.S. 359 (1931). See Aigler, Legislation in Vague or General Terms, 21 Mrcx. L. Rev. 831 (1923); Note, 26 TEx. L. Rev. 216 (1947); Note, Indefinite Crilcria of Definiteness in Statutes, 45 HARv. L. REv. 160 (1931). In United States v. Petrillo, 332 U.S. 1 (1947), in ruling on the Lea (Anti-Petrillo) Act, the Court held there was a sufficient measure of certainty but seemed to rely heavily on a conclusion that Congress could not have worded the statute more precisely. Id. at 1541. Such does not seem to be the case in $\$ 304$. Certainly Congressional debate (most ambiguous in the case of $\S 304$ ), even if crystal clear, need not be determinative. Mr. Justice Holmes is known to have pointed out that "when counsel talked of the intention of a legislature, I was indiscreet enough to say I don't care what their intention was. I only want to know what the words mean." Letter of Mr. Justice Holmes quoted in Frankfurter, Somt Reflections on the Reading of Statutes, 47 CoL. L. REv. 527, 538 (1947).

If the Court, either by restricting the scope of "expenditure" or by invalidating $\$ 304$ for vagueness, does not reach the constitutional issue under the First Amendment, much of this constitutional analysis may be irrelevant.

32. Perhaps the frankest statement by the Court of its substitution of its own evaluation of a civil liberties situation for that of Congress is Mr. Justice Rutledge's in Thomas v. Collins, 323 U.S. 516, 531 (1944). He pointed out that the ". . . judgment in the first instance is for the legislative body. But in our system where the line can constitutionally be placed presents a question this Court cannot escape answering independently, whatever the legislative judgment. . . " But cf. Colegrove v. Green 328 U.S. 549,56 YALE L. J. 127 (1946) (refusal to review inequities of Illinois Congressional districting); and Cook v. Fortson, 329 U.S. 675 (1946) (per curiam refusal to rule on constitutionality of Gcorgia county electoral system).

33. Mr. Justice Stone's famous footnote gloss in United States v. Carolene Products Co., 304 U.S. 144, 152, n. 4 (1938), spelled out for the first time the Court's need for a "more searching judicial inquiry" where political processes are at stake. One of the 


\section{Political Expenditures and The First Amendinent}

Supporters of Section 304 might argue that the statute places no restriction on freedom of speech since it prohibits only expenditures of money and not the actual right to speak itself. Such a contention, would ignore the fact that, even in the 18th Century, the exercise of free speech often involved the expenditure of funds, as for example, in political pamphleteering. It is hardly to be supposed that the drafters of the Bill of Rights would have countenanced a restriction on such pamphleteering if couched in the form of a ban on expenditures. Moreover, civil and political rights have become more complex within the last decades than in our early constitutional days. No longer is the right to speak encompassed by freedom to mount a cracker-barrel. Instead, such mass communication media as newspapers, radio and motion pictures now provide techniques for reaching millions of people so as to make many traditional concepts of the right of free speech anachronistic.34 Since free access to channels of communication is the essence of free speech today, and access is impossible without large expenditures of money, the right to spend in order to be "free" to speak effectively would seem to be deserving of protection under the First Amendment.

The need for "effectiveness" of speech was recognized by the draftsmen of the Constitution itself in protecting the cognate freedom of assembly as a means of implementing free speech. This need has also been recognized by the Supreme Court, which has gone far beyond protecting the naked right, to insure the effective right, to free speech. The Court has struck down a wide range of burdensome restrictions which, while they did not actually forbid free speech as such, made its exercise within significant contexts impossible. ${ }^{35} \mathrm{By}$

strongest supporters of a presumption of constitutionality of legislation, $\mathrm{Ar}$. Justice Stone nevertheless himself sounded a caveat which marked the new Court's change in attitude.

Heavily relied on in Gitlow v. New York, 268 U.S. 652 (1925), and Whitney v. California, 274 U.S. 357 (1927), the presumption of constitutionality of statutes regulating political and civil rights was given less effect in Near v. Minnesota, 283 U.S. 697 (1931). In Thomas v. Collins, 323 U.S. 516, 530 (1945), the presumption was said to be balanced by the "preferred place" given to the freedoms secured by the First Amendment. For a history of the shift, see Shulman, The Supreme Court's Aftilude Toutard Liberly of Contract and Freedona of Speech, 41 YALE L. J. 262 (1931); see also Hamilton, The Jurist's Art, 31 Cor L. Rev. 1073 (1931). A significant documentation has been collected in the following notes: 40 CoL. L. Rev. 531 (1940); 39 CoL. L. REv. 1237, 1242 (1939) ; 38 ArICr. L. Rev. 57, 60 (1939). For a more general treatment consult Hamilton and Braden, The Special Competence of the Supreme Court, 50 Y ALE I. J. 1319, 1349 (1941) and Lusly, Minority Rights and the Public Interest, 52 YALE L. J. 1 (1942). It must be recognized, however, that the shift in doctrine has been almost entirely spelled out in cases dealing only with state legislation although on its face it seems equally to apply to federal enactments.

34. See Cosmin on Freedour of the Press, A Free and Responstree Press (1947), 57 YaIE L. J. 894 (1948).

35. Religious and political groups may meet in public streets, parls, or on private property, scatter about or peddle pamphlets, canvass from door to door, play controversial records, and even create disturbances short of a breach of the peace without fear of sanetion. See Schneider v. State, 308 U. S. 147 (1939); Lovell v. Griffin, 303 U.S. 444 (1938); 
restricting expenditures, Section 304 strikes indirectly, but nevertheless effectively, at freedom of speech. The draftsmanship of the Constitution, its interpretation by the Court, and a realistic appraisal of our society today all argue eloquently that such a restriction, however indirect, is still a restriction.

It is also arguable on behalf of Section 304 that it restricts only the union's right to spend, leaving the individual's right to spend intact. This point of view might assume legal significance if the Court should accept a distinction between the individual union member's personal expenditure and his expenditure as a member of a labor organization. But the First Amendment speaks in blanket terms of a prohibition against Congressional regulation of free speech, press, and assembly in general, without reference to "persons" or "citizens," categories which have been known to exclude trade unions and corporations in the application of the Fourteenth Amendment." The question as to "whose right" need not arise, since all rights are protected.

Furthermore, the Court has by necessary inference protected the rights of unions and other unincorporated associations by protecting the individual member, as in Thomas $v$. Collins, ${ }^{37}$ where the Court struck down a Texas registration statute designed to curb labor unions, because it infringed 'Thomas'

Martin v. Struthers, 319 U.S. 141 (1943); Cantwell v. Connecticut, 310 U.S. 296 (1940); Hague v. CIO, 307 U.S. 496 (1939) ; Marsh v. Alabama, 326 U.S. 501 (1946). But cf. Chaplinsky v. New Hampshire, 315 U.S. 568 (1942).

36. The Fourteenth Amendment grants to corporations a curious congeries of rights. Since the corporation is an artificial, unnatural "person" it is often denied civil rights granted to natural persons by the due process and privileges and immunities clauses of the Fourteenth Amendment. Northwestern Life Ins. Co. v. Riggs, 203 U.S. 243, 255 (1906) (state statute depriving life insurance companies of defense based on false statements in applications unless contributory to death of insured); Western Turf Ass'n v. Greenberg, 204 U.S. 359, 363 (1907) (state statute regulating admission of persons to places of public entertainment); Hague v. CIO, 307 U.S. 496, 514, 527 (1939) (American Civil Liberties Union, a corporation, has no standing as "citizen"). See Elliott, Some Constitulional Aspects of Corporate Citizenship, 16 Geo. L. J. 55 (1927). But cf. Independent Servico Corp. v. Tousant, 56 F. Supp. 75, 78 (1944) (where free speech is involved, the corporation might be able to invoke the Fourteenth Amendment); and Grosjean v. American Press Co., 297 U.S. 233 (1936), Bridges v. California, 314 U.S. 252 (1941), and Pennekamp v. Florida, 328 U.S. 331 (1946) (Fourteenth Amendment rights of freedont of press were upheld as to corporations).

Although a labor organization has not been thought of as a "person," it has been noted by at least one commentator on the Taft-Hartley Act that "constitutional protections may surround a labor organization, as a 'citizen'." VAN ARKEL, AN ANALYSSIS of THE LAyOn Management Redations Acr, 194769 (1947). This is probably not the case, however, since the opinions in the cases cited supra state specifically that only natural persons are entitled to the privileges and immunities of citizens; cf. United States v. White, 322 U.S. 694 (1944) (Sixth Amendment), discussed infra note 39. Apparently, in the Hagle case it was the individual union members whose prevailing rights protected the union, which had no standing.

37. 323 U.S. 516 (1945). The right of individuals of any class or group to assemble into organizations which take political action is protected as a concomitant of the right of assemblage in the First Amendment as absorbed into the Fourteenth Amendment. De Jonge v. Oregon, 299 U.S. 353 (1937); Hague v. CIO, 307 U.S. 496 (1939). 
individual right to freedom of speech, although he spoke as a union organizer. Although the union's right to free speech was not formally before the Court, yet the union as a group was effectively protected by Thomas' individual right. $^{38}$ It might be claimed, however, that Thomas' individual right was inseparable from the rights of the union in the Thomas case, whereas in Section 304 there are separable rights - the right of the individual, which is protected, and the right of the union as a group, which is unprotected.so But the reasons advanced in refutation of the asserted dichotomy between the right to speak and the right to make expenditures in the exercise of free speech ${ }^{40}$ apply equally to a division, under the First Amendment, between the individual and the group to which he belongs. 'Moreover, even though traditional concepts of freedom have been largely cast in terms of the individual, ${ }^{11}$ it should be recalled that freedom of assembly is a group freedom. Particularly where few individuals are in a position to make large expenditures, if free speech is to be effective, individuals must be allowed to express their views through groups.12

38. This would seem to be Thomas' right as a union member, not as an official, on the theory that the individual member is able to assert his personal right to protect his stake in group activity.

39. A similar argument was presented by Counsel for Respondent, State of Alabama, in Federation of Labor v. MIcAdory, 325 U.S. 450 (1945), where it was claimed that the penal provisions of $\$ 18$ of Alabama's Bradford Act, a comprehensive law regulating the activities of labor organizations in Alabama by means, inter alia, of annual reports, work permits, and campaign fund restrictions, were directed not against individual members of the union but only against the organization itself; and that individual rights, therefore, were not infringed. See Brief for Respondent, 36-9. But the court had no cecasion to discuss this argument since it did not reach the merits of the case. $C f$. United States v. White, 322 U.S. 694 (1944), where the privilege against self-incrimination was held to be a personal one unavailable either to a union or to the custodian of union records acting in his official capacity. The distinction, however, between the privilege against self-inerimination and the freedom of speech or press seems clear. See Afr. Justice Cardozo, writing in Palko v. Connecticut, 302 U.S. 319, 325-7 (1937). Historieal and functional analyses indicate that fundamentally different purposes underlie their protection. Whether fostered by a sentiment which "recoils from forcing another human being" by physieal torture or imprisonment "to supply by his own act the incriminatory evidence," 8 Wrgsons, Evinasice $\$ 2259$ a (2d ed. 1923), or by a desire to compel the prosecution to search for independent evidence instead of relying on compulsory self-disclosure, United States v. White, sifro at 698 , the privilege against self-incrimination is "essentially a personal one, applying only" to natural individuals." Ibid. A union is not an appropriate subject for physieal compulsion. Where most of the evidence incriminating such an organization must be found, if at all, in its records, a search for independent evidence would prove largely futile. Id. at 700; \& WIGATORE, EVIDENCE $\$ \S 2259 \mathrm{a}$, 2259bb (2d ed. 1923). See generally, in adcition, Wilson v. United States, 221 U.S. 361 (1911); Hale v. Henkel, 201 U.S. 43 (1906). On the other hand, freedom of speech and of press serves to insure dissemination of "the widest possible information" essential to democratic political processes. See pp. \$246 infra. Hence the distinction drawn between individual and group in the matter of selfincrimination seems scarcely applicable here.

40. See pp. 815-6 sitra.

41. "The central theme in our American heritage is the importance of the individual person. ... The welfare of the individual is the final goal of group life." Tae Pnesrdent's Conisittee on Civil Rignts, To Secure These Rights 4 (1947).

42. See Bowe v. Secretary of the Commonwealth, 320 11ass. 230, 69 N.E.2d 115 


\section{Political Expenditures and the "Clear and Present Danger" Test}

The right to speak and the right to make expenditures for group political activity, then, are correlative. Yet Congress has sought their curtailment. Where inroads have been made into an area surrounded by constitutional "no-trespassing" signs, a critical examination of the justification for such action seems in order. The standards which must be met if legislation making these inroads is to be sustained have been traditionally cast in terms of the "clear and present danger" test. ${ }^{43}$ The test provides that the legislature may not limit freedom of speech nor press merely for the sake of private or public convenience, but may restrict it only where the state itself is threatened by such substantive evils as destruction of life or property, breach of peace, or other violent evils both serious and imminent.44 The Supreme Court has, however, been known to ignore the syntax of the test, even in free speech cases and to discuss simply the reasonableness of the legislation. ${ }^{45}$

Of many-justifications suggested for restriction of labor union expenditures perhaps the most consistently urged is that minority members of trade unions are coerced into financial support of political objectives with which they are

(1946), where the court, striking down a prohibition on union political expenditures, pointed out that "Individuals seldom impress their views upon the elcctorate without organization. They have a right to organize into parties, and even into what are called 'pressure groups,' for the purpose of advancing causes in which they believe. They have a right to engage in printing and circulating their views, and in advocating their cause in public assemblies and over the radio. All this costs money, and if all use of money were to be denied them the result would be to abridge even to the vanishing point any effective freedom of speech, liberty of the press, and right of peaceable assembly." Id. at 252, 69 N.E.2d at 130.

43. First formulated by Mr. Justice Holmes in Schenck v. United States, 249 U. S. 47,52 (1919), the test as classically stated protects utterances which do not "create a clear and present danger that they will bring about the substantive evils that Congress has a right to prevent." These "substantive evils" have never been adequately defined and are subject to considerable controversy. "Like many other rules for human conduct [the test] can be applied correctly only by the exercise of good judgment. . . " Schaefer v. United States, 251 U. S. 466, 482-3 (1920) (dissenting opinion). Although it fell into discard, the test was revived in a 5-4 decision in Herndon v. Lowry, 301 U. S. 242, 256 (1937). The obvious ambiguity of the test as it stands has led to some criticism. Sec Wechsler, in Symposium on Civil Liberties, 9 Ax. L. ScHool Rev. 881 (1941). But the Court continues to use it to strike down legisiation. See generally, ChafeE, FreE Speech in the United States (1941) passin.

44. See Thornhill v. Alabama, 310 U.S. 88, 104-5 (1940).

45. The Court in sustaining legislation, challenged as violative of the First Amendment, ignored the "clear and present danger" test in the following: Public Workers v. Mitchell, 330 U.S. 75 (1947); Carpenters and Joiners Union v. Ritter's Cafe, 315 U.S. 722 (1942) ; Drivers' Union v. Meadowmoor Dairies, 312 U.S. 287 (1941) ; Gitlow v. New York, 268 U.S. 652 (1925) ; Pierce v. United States, 252 U.S. 239 (1920); Schacfer v. United States, 251 U.S. 466 (1920) ; Abrams v. United States, 250 U.S. 616 (1919). Somc cases have protected freedom of speech, press, assembly and religion without expressly using the clear and present danger test. See AFL v. Swing, 312 U.S. 321 (1941); Schneider v. State, 308 U.S. 147 (1939) ; Lovell v. Griffin, 303 U.S. 444 (1938); De Jonge 
not in sympathy and as to which they have no freedom of choice, ${ }^{40}$ since the union shop, sanctioned by the Taft-Hartley Act, helps to afford unions control over the labor market.47

Although it is recognized that some oligarchically controlled unions do abuse their economic and political power, it would seem that the union member is protected where union elections and significant political expenditures are given democratic guarantees. Such guarantees could be secured by legislation which would protect the democratic processes within the union, 18 or which would require majority consent to political expenditures. ${ }^{48}$

It might perhaps be argued that further protection for dissenters would be inconsistent with the purposes implicit in Congressional recognition of the union shop, for by sanctioning the union shop Congress has already sanctioned a restraint on the rights of a minority in the furtherance of reasonable union objectives. ${ }^{.0}$ Hence the proponents of additional restrictions on union

v. Oregon, 299 U.S. 353 (1937); Near v. Minnesota, 283 U.S. 697 (1931); Stromberg v. California, 283 U.S. 359 (1931).

46. Senator Taft expressed this view in Congressional debate, asking "Why should [union members] be forced to contribute money for the election of someone to whose clection they are opposed?" 93 Cong. Rec. 6440 (1947); and more recently went so far as to suggest that the aim of $\$ 304$ was merely to protect dissenting union members. N.Y. Herald Tribune, Feb. 26, 1948, p. 2, col. 3. See note 20 sapra. This attitude has also been vigorously articulated by a Boston journalist in Mullins, I Object to dfy Union in Polities, Readers Digest, Sept. 1944, p. 9, and Waldman, Will the CIO Capture the Democrotic Party, Sat. Eve. Post, Aug. 26, 1944, p. 22. In more sophisticated form this argument is advanced in Braunthal, American Labor in Politics, 12 Soctar Resenscr 1, 9 (1945). Braunthal, a research economist for a union, recommends financing political campaigus by" voluntary contributions of union members as the "only sound demoeratic" way. See also SEN. REP. No. 151, 75th Cong., 1st Sess. 135 (1937).

47. The "closed shop," an even stronger hold on union members, has been barred by the Taft-Hartley Act, 61 SтAт. 140 (1947), 29 U.S.C.A. $\$ 158$ (a)(3) (Supp. 1947), but the "union shop," a less rigorous form of union security arrangement, has been permitted.

48. Democratic government of unions might be assured, for instance, by a requirement that there be annual elections of all officers of the union, with appropriate pomers granted these officers to appoint agents, organizers, and representatives. A majority of union members attending should be sufficient. Thus, union officials whose political policies are repugnant to the membership can be voted out of office. In addition, a further saieguard might be special sessions at which broad political policies would be voted upon. Such devices would curb oligarchic tendencies in trade unions. See Democracy with a Union Card in LeRnER, IdeAs ARE WeApors 517-33 (1939) and, generally, SETDisar:, Union Rights and Union Duties 20-52 (1943).

49. Since political expenditures by labor groups have formerly been of insignifieant importance, most union constitutions appear to afford few specific safeguards to union members. As to whether or not union funds generally have been used by officers of hbor organizations in conformity with majority wishes and in accordance with democratic procedures, see Overacker, Labor's Political Contributions, 54 PoL. Scr. Q. 56, 67-S (1939). A reasonable measure of self-regulation would not hamper union leaders and would easily furnish required minority protection. But see Bernstein, John L. Lezis and the Voting Behavior of the CIO, 5 PUB. Op. Q. 233 (1941).

50. Nor does this restraint appear to infringe upon dissenters' constitutional preroga- 
control of dissenters are in reality asserting that political activity is not such a reasonable objective. ${ }^{51}$ It has been suggested, however, by the district court opinion in United States v. Murray ${ }^{52}$ that even narrowly drawn legislation designed to protect the minority member at the expense of the union majority may be unconstitutional. Nevertheless, British experience has shown that specific legislation may be drawn, if necessary, to give dissenters this added protection..$^{53}$ Such legislation could take either of two forms: "contracting in," in which all members approving of the proposed assessment would be required to give affirmative evidence of such approval or "contracting out," in which

tives. Cf. DeMille v. American Federation of Radio Artists, 175 P.2d 851 (Cal. App. 1946), 60 HARv. L. Rev. 834 (1947), aff'd, 31 Cal. 2d 137 (1947), where an application by Cecil B. DeMille for reinstatement in his union and in a $\$ 98,200$ a year job was denied. Suspended from both for refusal to pay a $\$ 1.00$ assessment to support the union lobbying campaign on a labor issue, he had argued that the compulsory assessment infringed his "constitutional right of suffrage, freedom of speech, press and assembly." The court upheld his suspension in an opinion pointing out that submission to reasonable obligations democratically imposed could not be construed to infringe on fundamental individual rights. The Court, assuming the constitutionality of $\S 9$ of the Smith-Connally Act, sce p. 808 sipra, indicated that an assessment for political contributions would have been unsustainable. Absent a statutory prohibition on expenditures, therefore, it would seem, under the court's rationale, that the individual dissenter to union political expenditures would not be entitled to protection.

51. If dissidents are to be bound by the union majority in economic decisions even to the extent that they may be deprived of employment for failure to pay their dues, it might be argued that similar weight should be accorded political decisions democratically entered upon, provided these do not transgress the reasonable limits of union activity. Cf. Morgan v. Local 1150, United Electrical Workers, 16 LAB. REL. REP. 476 (IIl. Super. Ct. 1945) (individual expelled from union because of disagreement with its political policies had right to job but not to official union position). For an example of unreasonable political activity by a union, see Collins v. IATSE, 119 N.J. Eq. 230, 244, 182 Atl. 37, 45 (1935) (disapproving racketeering political contributions to candidates for the Newark City Commission where it was not customary for union to make such contributions). See, generally, Comarager, Majority Rule and Minority Rignts (1943); Baldwin, Union Administration and Civil Liberties, 248 Ansals 54 (1946); Witmer, Civil Libertics and the Trade Union, 50 Y AIE L.J. 621 (1941).

Furthermore, it would seem desirable where possible to encourage the diversion of techniques of economic warfare into political channels. See pp. 826-7 infra.

52. N. Y. Times, March 16, 1948, p. 24, col. 3.

53. The British experiment, abandoned recently by the Labor Government, had its genesis in a set of circumstances similar to present ones in the United States and-perhaps typically-several decades earlier. Labor's successful and ever-developing participation in English politics caused Conservatives much concern. At length, in 1910, suit was brought to enjoin a leading union from making political contributions to the Labor Party. Previous litigation had resulted in a decision legitimizing labor's political contributions, Steel v. South Wales Miners' Federation, [1907] 1 K.B. 361, but after extensive and bitter litigation the House of Lords, in Amalgamated Society of Railway Servants v. Osborne, [1910] A.C. 87, decided that the making of contributions to Labor M.P.'s was not one of the "legitimate objectives" of trade unionism, and that compulsory levies were tillra vircs. "Expenditures" were not affected.

The labor movement reacted to the Osborne decision with a wave of strikes. After some partial appeasements, a compromise was reached three years later which relieved 
the dissident union member would be required to indicate his non-assent to a proposed political assessment. Where it is possible to confine remedial legislation to the specific evil, it seems clear that so broadly repressive a measure as Section 304 reaches needlessly into labor's allowable area of political activity.

Another argument bases the validity of Section 304 upon the dangers from the influence of money in elections. ${ }^{.5}$ But no real danger to our democratic form of government has been demonstrated in labor's political expenditures."0

trade unions of the ultra vires restriction. Political contributions were permitted subject to majority decisions by rank and file members, with exemptions for those members who did not wish to contribute but who could, by affirmative action, "contract out" of a politial assessment. Following the disastrous 1926 General Strike, however, the Conservatives passed new legislation which amended the requirements so that members were required affirmatively to "contract in" by signifying a positive desire to contribute, even though a majority of members had approved the contribution. Thus, the burden of overcoming inertia was placed upon the union rather than upon the individual. Shortly after the Labor Party came to power in 1945, all limitations were repealed. It must be noted that at no time were union newspapers affected, a motion to include them in legislation having been rejected by the House of Commons as an undue limitation on union political power. Other "expenditures" were similarly protected at all times. See Rothschild, Government Regulation of Trade Ustions in Great Britain: II, 38 CoL L. Rev. 1335, 1353 et scq. (1938). See also Webs, The History of Trade Unionisis 608 et seq. (1920); 3 Cole, A Short History of the British Worktng Ciass Miovearent 54-61 (2d ed. 1937). For a brief discussion of the Trade Disputes Act of 1927 see Mason, British Trode Disputes Act of 1927, 22 Asr. PoL. Scr. Rev. 143 (1928). See also Pease, Trade Uniors and Trade Disputes in English Law, 12 CoL L. REv. 589, 595 (1912).

54. "The attempt to correct abuses of freedom ... by resort to legal penalties and controls is the first spontaneous impulse of reform. But the dangers of the cure must be weighed against the dangers of the disease. ..." TrE Cossur's o:: Fnesnoss of TIEE Press, A Free and Responsible Press 122 (1947).

A familiar criticism by the Court in civil liberties cases is that legislation is of too sweeping a character. Thus, in Schneider v. State, 308 U.S. 147, 162 (1939), the Court said, "This constitutional protection does not deprive a city of all powers to prevent street littering. There are obvious methods of preventing littering. Amongst these is punishment of those who actually throw papers on the streets." In De Jonge v. Oregon, 299 U. S. 353, 364-5 (1937), the Court struck down the application of a criminal syndiealism law, saying, "The people through their legislatures may protect themselves against . . . abuse [of incitement to violence and crime]. But the legislative intervention can find constitutional justification only by dealing with the abuse. The rights themselves must not be curtailed." See also Thomas v. Collins, 323 U.S. 516, 532 (1945) ; Cantwell v. Connecticut, 310 U.S. 296, $30 \mathrm{~S}$ (1940) ; Carison v. California, 310 U.S. 106, 112 (1940); Lovell v. Griffin, 303 U.S. 444, 451 (1938). See Note, Statutory Prohibition of Group Dcfanation, 47 CoL L. REv. 595, 607 (1947) ; Note, 5 U. of CHI. L. Rev. 675, 677 (1938).

55. Note Senator Bankhead's statement, in introducing an amendment to Hatch Act II, "We know that money is the chief source of corruption," quoted in Orenscken, Prestdental Cantpaign Funds 27 (1946), and see pp. S07-S supra. But see Clark, Federal Regulation of Election Campaign Activities, 6 FED. B. J. 5, 8 (1944) “. . . Congress has always recognized that expenditure of money in elections is not in itself evil. ...").

56. Much public attention was called to the threst of A. F. Whitney, President of the Brotherhood of Railroad Trainmen, that his union would spend forty-seven million dollars to defeat President Truman for re-election in 1948, and two and a half million dollars to defeat any Congressman who voted for restrictive labor legislation. N.Y. Times, May 27 , 1946. p. 1, col. 6. 
On the contrary, by promoting interest in the electoral process, labor seems to be enlarging democratic methods. ${ }^{57}$ Even if there were abuses inherent in labor's political activities, it would seem more appropriate for Congress to take steps which meet the specific evils. If, for example, it is feared that spending by labor leads to corruption, then a federal statute directly affecting such practices could be enacted, rather than broadly prohibitive legislation which affects basic freedoms. ${ }^{58}$ Not until specific prohibitions are found inadequate should Congress legislate in any broader manner.

Further argument in support of the legislation might be grounded upon the proposition that democracy is subverted where powerful groups are permitted to erect a political influence out of proportion to their numbers. But even if Congress could restrict free speech in order to strike at such an evil, there is little evidence that labor organizations exercise a disproportionate influence on the electoral process. ${ }^{59}$ The relatively insignificant role of labor is reflected in recent presidential elections where organized labor contributed but $4 \%$ to $7 \%$ of all campaign funds $;^{60}$ yet this percentage represents the contributions

57. For a comprehensive picture of labor's political activity consult Carroll, Lador and Politics (1923); H. L. Childs, Laeor and Capital in National Polutics (1930); Lorwin, The American Federation of Labor (1933); Perlaman, a Tueory of tule Labor Movement (1928); Schneider, Workers' (Communist) Pakty and AmerichN TrAde Unions (1928); Barbash, Unions, Government and Politics, 1 IndUST. ANd LAd. Rel. Rev. 66 (1947); Frey, Labor in Politics, 39 Amer. Federationist 1012 (1932); Rosenfarb, Labor's Role in the Election, 8 PUв. Op. Q. 376 (1944); Rovere, Labor's Political Machine, 190 HARPER's 592 (1945); Seidman, Organized Labor in Political Campaigns, 3 Puв. OP. Q. 646 (1939); Taft, Labor's Changing Political Line, 45 J. PoL. ECON. 634 (1937).

58. Congress, for example, may provide punishment for election officials for neglect of duty or for fraud, Ex parte Siebold, 100 U.S. 371 (1879); Ex parte Clarkc, 100 U.S. 399 (1879); In re Coy, 127 U.S. 731 (1888); candidates may be required to file sworn statements of campaign expenses, United States v. Cameron, 282 Fed. 684 (D. Ariz. 1922) ; Congress may punish for perjury in inquiries before it as to campaign expenditures of senatorial candidates, United States v. Seymour, 50 F.2d 930 (D. Neb. 1941).

59. Labor's expenditures in national campaigns before 1936 were small and sporadic. In that period the AFL expended a bare $\$ 100,000$ for political purposes from general treasury funds, and made no contributions to candidates or parties whatsocver. But in the 1936 election contributions from labor unions assumed new significance. And Cro unions, including the expenditures by their own political organizations and contributions to the Democratic Party, spent almost three quarters of a million dollars in the 1936 campaign. The percentage contributed by labor, however, was still small. For a ready compilation of data, see Overacker, Labor's Political Contributions, 54 Por. Scr. Q. 56 (1939). It should be understood that labor's "expenditures" cannot be computed as easily as "contributions," since political expenditures are often intangible and are inextricably woven with other non-political expenditures; labor's total political activity is undoubtedly greater than indicated by figures on sums actually contributed to party funds.

60. In the 1944 election, unions could not contribute qua unions. The CIO-PAC, however, spent nearly a haif million dollars of union funds for education and pre-campaign publicity and collected another half million for the campaign itself. But the total of all contributions to the campaign was estimated at neariy $\$ 21,000,000$. See Overacker, Presidential Campaign Futds, 1944, 39 AM. Poz. Scr. Rev. 899, 906, 921 (1945). Organizcd 
of fourteen million union workers. ${ }^{61}$ There is also considerable evidence that other groups enjoy a peculiarly advantageous monopoly in the opinion industries in that the press, radio, and motion picture industry represent and articulate the point of view of their owners, managers and advertisers. ${ }^{02}$ And there is reason to believe that this control has been used so as to discriminate against labor's participation in the opinion-influencing process. ${ }^{.3}$ Labor's political influence in proportion to its numbers does not seem "unreasonable," and certainly does not present a "clear and present danger" to the electoral process.

labor had contributed $5.1 \%$ of the funds of the Democratic National Committee in 1936, and $6.2 \%$ in 1940, and little, if any, to other parties. Overacker, Campaigrs Finanec in the Presidential Election of 1940, 35 Aar. Por. Scr. Rev. 701, 715 (1941).

61. Peterson, Asrerican Lazor Unions 33-4 (1945).

62. Hays, Civic Discussion Over the Air, 213 Amwars 37, 44 (1941); Azigan, Frons Chaos to Control 4 (1932); Freedom in the Opinion Industrics in Leriter, Iosas ARE WeApons 13-24 (1939), and The Barons of Opintion in LERNER, IT Is LATER THAN: you Think 127-134 (1943); Lassweri, Dearocracy Throvgr Punlic Opniro: (1941). There are large combinations within each of the three major opinion industries (press, radio, films) and important groups are active in two or more of these. The Luce group controls four magazines and a motion picture company. The Cowles brothers own four newspapers, four radio stations and a weekly picture magazine. MFarshall Field runs one metropolitan newspaper, four radio stations, a farm journal, and a Sunday supplement used by more than forty newspapers. Hearst at one time controlled twenty-six newspapers, thirteen magazines, eight radio stations, a newsreel company, an interest in a motion picture feature producing company, a lending feature syndicate, and one of three press associations. Consasission on Fresdour of the Press, A Free arid Resfosisume Press 44-46 (1947). For data on the labor press see 1 Reywolds A3id KunIwGsworrtr, Trade Union Publications c.1 (1944).

63. For discussion of discrimination in the press, see Keezer, 12 Evcrc. Soc. Scr. 325, 338-41; Martin, Freedont of the Press, 9 PoL. Q. 373 (1938); Axanu, Way Fresnom MatTers 123-4 (1940); Whitney, Labor Gets No Brcal in the Press, and Bliven, Balance Sheet for American Joumalismz in Ickes, Freedoss of the Press TOdAx (1941).

For discussion of discrimination in radio see Steparama, Radio's Secondd Canzice 104 et seq. (1947); Radio Program Controls: A Networls of Inadequacy, 57 Yale L. J. 275 (1947); Sussman, How Radio Treated Labor in the Elcctions, 14 Cosaso: Sewse 34 (1945); Stewart, Radio Commentators and Frec Speceh, 14 Coxnson SE:se 32 (1945); Chase, Sound and Funy 128-9 (1942). See also Brozdeasting, Jan. 20, 1947, p. 13, col. 1. Consult also Elsten, Mass Consmsusication ar:d Aneriean Democracy in Print, Radio and Finsr in a Descocracy, esp. p. 10 (Waples ed. 1942); Frost, Is American Radio Dearocratic? (1937); Kerwin, The Control of Radio, Public Policy Paxtrelet No. 10 (1934); Friedrich, The FCC 'Monopoly' Rcfort: A Critical Appraisal, 4 PuB. Op. Q. 526 (1940). Siepararrs, Radro's Seco:id Cinazice 104 et seq. (1947) notes the discrimination against labor groups, especially during election periods. Prior to the petition filed before the FCC by the CIO in 1943, requesting that the license of WHKC be denied renewal, broadcasters generally refused to sell time for any union programs on the ground that these programs were "almost always of a controversial nature." But where a business concern sponsored a program, discussion of such subjects as rationing, price control, taxation, international affairs, or labor problems became non-controversial per se. Perhaps this is because the function of radio, as expressed by a network president is "selling time for one specific reason, and that is to sell goods manufactured by American manufacturers, to the public." See Durr, Freedoms of Speceh 


\section{Political Expenditures and Federal Elections}

However justified legislation curbing political contributions may be in the light of Congressional responsibility for federal elections, ${ }^{64}$ it seems clear that equal justification does not exist for a broader prohibition on expenditures. ${ }^{\text {at }}$ In fact, it may be urged that political expenditures in a democratic society serve to implement rather than to obstruct the electoral process.

If rational political decisions are to be made, the electorate must have access to factual information and conflicting opinions from all groups. ${ }^{66}$ In Holmes' classic metaphor, the truth can be discovered only in a free market place of ideas. ${ }^{67}$ The First Amendment, in guaranteeing freedom of speech, assembly, and press, ${ }^{88}$ supports "the widest possible dissemination of information from diverse and antagonistic sources." But the furnishing of information and opinion is no longer the inexpensive undertaking that it was in Thomas Jefferson's day; when even the candidate himself is reputed to have expended but fifty dollars in his Presidential campaign. ${ }^{70}$ With the advent of new tech-

for Whom? 8 PuB. Op. Q. 391,399 (1944). The NAB Code Manual warns that "[cmployers] . . . are inclined to frown on those stations, especially in smaller communities, which open their facilities to labor unions." Id. at 400 . See also Note, The Frecdom of Radio Speech, 46 Harv. L. REv. 987 (1933).

64. See note 8 and pp. 813-4 supra. Cf. United Public Workers of America v. Mitchell, 330 U.S. 75 (1947), 47 CoL. L. Rev. 295 (1947); Oklahoma v. Civil Service Comm'n, 330 U.S. 127 (1947) (Hatch Act restrictions on political activity of state and federal employees are constitutional). It has been suggested, however, with respect to political contributions, that "free and prompt publicity" of the source of the contributions is more desirable than their prohibition. SEN. REP. No. 101, 79th Cong., 1st Sess. 83 (1945).

65. In United States v. Murray, N.Y. Times, March 16, 1948, p. 24, col. 5, the Mitchell case, note 64 supra, was distinguished on two grounds: that restrictions on the political activity of federal employees were justified, not on the basis of Congressional power to regulate elections, but on the right of government to prescribe rules of conduct for its own employees; and that regulation of political activities is not equivalent to a prohibition of political expenditures since the latter, as applied to labor organizations, "absolutely" forecloses any action in connection with elections.

66. "If then we desire to keep the freedom we have had and the humane spirit of our civilization, it is necessary for us to know our theory and practice of popular government, and to equip ourselves with information and understanding for the purpose of upholding it, developing it, and making it more effective. . ." BEARD, AMERICAN GovERNMENT AND Politics 2 (1939). See also KeY, op. cit. supra note 7, at 488; Riesman, Education for Democracy, 5 PuB. Op. Q. 195 (1941).

Where the information is "bad"-that is, where political propaganda is defamatory, specific measures can curb such an abuse. See Bone, Smenr Pourtics (1941), which presents evidence that an increasing amount of political propaganda refers to general political issues in a defamatory manner. Suggestions for control of this type of abuse are outlined in Note, Statutory Prohibition of Group Defamation, 47 Cot. L. REv. 595 (1947).

67. Abrams v. United States, 250 U.S. 616, 630 (1919) (dissenting opinion).

68. See Lovell v. Griffin, 303 U.S. 444, 452 (1938) ("The liberty of the press is not confined to newspapers and periodicals. It necessarily embraces pamphlets and leaflets.")

69. Associated Press v. United States, 326 U.S. 1, 20 (1945).

70. Merriam and Gosneli, op. cit. supra note 7, at 361 . 
niques and channels of communication, ${ }^{71}$ political costs have risen steeply. ${ }^{\text {i2 }}$ In addition to population increases, new areas have been developed and basic services have risen in price. Large scale printing, direct mail distribution, newspaper advertisements, billboards, auditorium space, radio broadeasting time, and motion pictures,-all have added to the expense of publicizing divergent viewpoints on political issues. ${ }^{73}$ To the extent that political expenditures are curtailed, the education of the American electorate will suffer.

If government is to remain responsive to the needs of all groups in the population, ${ }^{74}$ these groups must be able to influence the decision-maling process. ${ }^{75}$ The union has of late concerned itself with the wage-earners' stake in such vital legislative issues as taxation, housing, rent and price control, full $\mathrm{em}$ ployment, minimum wages, health, education, and the elimination of discrimination in employment. Recent years have witnessed a growing participation by union officials in political life, in administration affairs as well as in the

71. "... we have allowed our ideas about these rights [of speech and press] to remain static while the facts about them have greatly changed. . . Public opinion now is formed by many devices other than assembly or speech or the press . . new phasas of life have taken their place. Radio broadcasts, syndicated columnists, newsreels, public relations counsel, news weeklies, press bureaus ... and many other devices now tell us many things ... the tools of propaganda and the techniques available for making effective use of them have been modernized." Cherington, Our Frecolons and Our Ofinions, 6 PuB. Op. Q. 616 (1942).

72. While figures for total expenditures "in connection with elections" are naturally unavailable, expenditures out of contributions to political parties have risen from almost $\$ 4,500,000$ in 1916 to almost $\$ 21,000,000$ in 1944 . From 1912 to 1928 costs per vote fluctuated between 15 and 20 cents, but in the last three Presidential elections for which figures are available the cost per vote has risen to 32 cents. See Overncrien, MIO:*EY In Electrons 75-6 (1932); Overacker, Campaign Fussds in a Depression $Y$ car, 27 Ass. PoL. ScI. Rev. 769, 771 (1933); Overacker, Campaign Funds in the Presidertial Elcelion of 1936, 31 Axr. PoL. SCL. Rev. 473, 477 (1937).

Contributions to political campaigns furnish a rough index of the increasing cost of influencing public opinion. It would appear, therefore, that groups who wish to influence public opinion outside of the political party must themselves spend more to malee themselves heard.

73. See Logar, op. cit. supra note 7, at 185-94.

74. Riesman, Civil Libcrtics in a Period of Transilion, 3 Punuc Pourer 83 (Friedrich and Mason eds. 1942), has pointed out that "The coneept which sees the problem of political power raised only by tension between 'the individual' and 'the state' fails to recognize that political power is not a monopoly of the state and that the enjoyment of civil liberties depends upon one's group affiliations and hostilities. ... Only an approach tinctured with pluralism can do justice to the variety of situations in which problems of civil-liberty character present themselves; in trade unions, corporations, universitic, professional associations, and so forth." For a literature on pluralism, sce Hsmo, Pourrcas Pluzaltsar (1927); Figgis, Studies of Folmical Thotgem Frovs Genso:: to Grotius (1907); Laskx, A Grascaras of Polrtics (1925); Colser, The Techimigue of the Pluralistic State, 15 Ans. PoL. Scr. Rev. 186 (1921); Ellis, 7thc Pluralistic Statc, 14 A.r. Por. Scr. Rev. 393 (1920) ; Sabine, Pluralisms: A Point of Vicu, 17 Aar. Por. Ser. Rrv. 34 (1923).

75. See Mlosca, The Ruling Class esp. c. 5, (1939). And see lasswerd, op. cit. 
formulation of legislation. ${ }^{76}$ This sharing in political activity has correspondingly afforded individual wage earners an opportunity to "participate in making the decisions that vitally affect them in their work and community life."77 By curtailing union political expenditures, Congress moves toward the isolation of representative government from the wage earner point of view. To the extent that the strictures of Section 304 decrease the capacity of one or more groups to participate in the political process, ${ }^{78}$ to that extent groups and ideas already in power can more easily perpetuate themselves. ${ }^{70} \mathrm{~A}$ representative government must represent more than itself.

\section{CONCLUSION}

Both courts and legislature have recognized a clear public interest in the efficient functioning of such groups as labor organizations. For many labor unions political activity has become a necessary method of complementing economic action with favorable legislation. ${ }^{80}$ There is a powerful incentive for

supra note 62, c. 10 (1941) ; Lasswell and McDougal, Legal Education and Public Policy 52 YALE L. J. 203, 226-7 (1943).

76. In addition to the fact that both AFL and CIO have representatives serving as Assistant Secretaries of Labor, numerous labor leaders have served in many governmental capacities. Sidney Hillman served in several influential governmental positions, including that of Associate Director of OPM. Many labor leaders were represented on the War Labor Board. Representatives of labor appear regularly before Congressional Committees. See Witmer and Lund, Labor-Work Plics Ideals, 7 Pü. Or. Q. 378, 386, 388 (1943).

77. Golden and Ruttenderg, The Dynamics of Industrial Democracy 3 (1942).

78. The effect of $\S 304$ on other groups is not within the scope of this discussion. See p. 807 supra.

Should $\$ 304$ apply unequally in its effects on unions and on corporations, even though both are nominally included in the Act, it might be argued that it infringes the Fifth Amendment. Cf. United States v. Murray, N.Y. Times, March 16, 1948, p. 24, col. 1, where the argument was raised but not passed upen. Although the Fifth Amendment contains no equivalent of the "equal protection" clause in the Fourteenth Amendment, Detroit Bank v. United States, 317 U.S. 329, 337 (1943), it has been construed to restrain "such discriminatory legislation by Congress as amounts to a denial of due process." See Hirabayashi v. United States, 320 U.S. 81, 100 (1943). See also Currin v. Wallace, 306 U.S. 1,14 (1939). But cf. United States v. Petrillo, 332 U.S. 1 (1947); NLRB v. Jones and Laughlin Steel Corp., 301 U.S. 1, 46 (1937).

79. Mr. Chief Justice Hughes perhaps articulated, in De Jonge v. Oregon, 299 U.S. 353, 365 (1937), the basic premise of the First Amendment: ". . . to maintain the opportunity for free political discussion, to the end that government may be responsive to the will of the people and that changes, if desired, may be obtained by peaceful means. Therein lies the security of the Republic, the very foundation of constitutional government." Accordingly, the need seems clear to keep open to all groups "the remedial channels of the democratic process," Minersville School District v. Gobitis, 310 U.S. 586, 599 (1940) (Frankfurter, J.), although use of these channels may not "always be agreeable to those in authority or ... wise, temperate or useful to society." Thomas v. Collins, 323 U.S. 516, 545 (1945) (Jackson, J., concurring opinion).

80. "Free speech on both sides and for every faction on any side of the labor relation is to me a constitutional and useful right. Labor is free to turn its publicity on any 
unions to divert techniques of economic warfare into political channels where it is possible to do so, to the inestimable advantage of a sensitive economy easily thrown into disequilibrium by industrial strife. And it has been recognized that the individual worker gains equality of economic power with management only through his labor organization, through which it is possible for him to do in combination with others what he cannot do singly. 81

Where a political relationship parallels the employer-employee relationship, group association seems equally necessary if the union member as an individual is not to find the task of opposing powerful pressure groups an unequal one. Unless he may associate himself with others in molding public opinion, his voice may not be heard in the electoral process. Unless the association may undertake political expenditures, it cannot utilize the channels of communication through which public opinion is formed.

The prohibition on political expenditures, then, does not seem justifiable in terms of any furtherance of democratic electoral processes. Accordingly, Section 304 would seem to fall within the ban of the First Amendment forbidding abridgement by Congress of freedom of expression through free association.

labor oppression, substandard wages, employer unfairness, or objectionable worling conditions." Mr. Justice Jackson, in Thomas v. Collins, 323 U.S. 516, 547 (1945) (concurring opinion).

The late Sidney Hillman indicated that the CIO secured many of its aims by "political action" as well as economic action. Barbash, Unions, Goverrartert ord Polities, 1 INDUST. AND LABOR REI. REv. 66, 68, 69 (1947).

81. NLRB v. Jones \& Laughlin Steel Corp., 301 U.S. 1 (1937). 